\title{
Endoscopic duodenal-jejunal bypass liner rapidly improves plasma parameters of nonalcoholic fatty liver disease
}

Citation for published version (APA):

de Jonge, C., Rensen, S. S., Koek, G. H., Joosten, M. F., Buurman, W. A., Bouvy, N., \& Greve, J. W. (2013). Endoscopic duodenal-jejunal bypass liner rapidly improves plasma parameters of nonalcoholic fatty liver disease. Clinical gastroenterology and hepatology, 11(11), 1517-1520. https://doi.org/10.1016/j.cgh.2013.07.029

Document status and date:

Published: 01/11/2013

DOI:

10.1016/j.cgh.2013.07.029

Document Version:

Publisher's PDF, also known as Version of record

\section{Document license:}

Taverne

Please check the document version of this publication:

- A submitted manuscript is the version of the article upon submission and before peer-review. There can be important differences between the submitted version and the official published version of record.

People interested in the research are advised to contact the author for the final version of the publication, or visit the DOI to the publisher's website.

- The final author version and the galley proof are versions of the publication after peer review.

- The final published version features the final layout of the paper including the volume, issue and page numbers.

Link to publication

\footnotetext{
General rights rights.

- You may freely distribute the URL identifying the publication in the public portal. please follow below link for the End User Agreement:

www.umlib.nl/taverne-license

Take down policy

If you believe that this document breaches copyright please contact us at:

repository@maastrichtuniversity.nl

providing details and we will investigate your claim.
}

Copyright and moral rights for the publications made accessible in the public portal are retained by the authors and/or other copyright owners and it is a condition of accessing publications that users recognise and abide by the legal requirements associated with these

- Users may download and print one copy of any publication from the public portal for the purpose of private study or research.

- You may not further distribute the material or use it for any profit-making activity or commercial gain

If the publication is distributed under the terms of Article $25 \mathrm{fa}$ of the Dutch Copyright Act, indicated by the "Taverne" license above, 


\title{
BRIEF COMMUNICATION
}

\section{Endoscopic Duodenal-Jejunal Bypass Liner Rapidly Improves Plasma Parameters of Nonalcoholic Fatty Liver Disease}

\author{
CHARLOTTE DE JONGE,,*, SANDER S. RENSEN, ${ }^{*}$ GER H. KOEK,, MANDY F. JOOSTEN, ${ }^{\star}$ WIM A. BUURMAN, ${ }^{*}$ \\ NICOLE D. BOUVY, ${ }^{*}$ and JAN WILLEM M. GREVE ${ }^{\ddagger}$ \\ *Department of General Surgery and NUTRIM School for Nutrition, Toxicology and Metabolism Research, Maastricht University Medical Center, Maastricht; \\ ${ }^{\ddagger}$ Department of General Surgery, Atrium Medical Center Parkstad, Heerlen; and ${ }^{\S}$ Department of Internal Medicine, Division of Gastroenterology \\ and Hepatology and NUTRIM School for Nutrition, Toxicology and Metabolism Research, Maastricht University Medical Center, Maastricht, the Netherlands
}

Bariatric surgery reduces nonalcoholic fatty liver disease (NAFLD). We investigated the effects of duodenal-jejunal bypass liner (DJBL), nonsurgical bariatric device, on plasma parameters of NAFLD. Seventeen obese subjects with type 2 diabetes received the DJBL for 24 weeks. Before, during, and after DJBL implantation, we determined plasma levels of aspartate aminotransferase (AST), alanine aminotransferase (ALT), $\gamma$-glutamyltransferase $(\gamma-G T)$, albumin, caspase-cleaved cytokeratin-18 (CK-18), and liver fatty acidbinding protein (L-FABP). At baseline, subjects had increased levels of AST (35 $\pm 4 \mathrm{IU} / \mathrm{L})$, ALT (54 $\pm 5 \mathrm{IU} / \mathrm{L})$, and $\gamma$-GT (66 $\pm 14 \mathrm{IU} / \mathrm{L})$, compared with healthy individuals; subjects' mean concentrations of caspase-cleaved CK-18 and $\mathrm{L}$-FABP were $214.4 \pm 35.6 \mathrm{U} / \mathrm{L}$ and $29.3 \pm 2.6 \mathrm{ng} / \mathrm{mL}$, respectively. Three months after implantation of DJBL, all NAFLD-related parameters had decreased from baseline (AST, $28 \pm 3 \mathrm{IU} / \mathrm{L} ; \mathrm{ALT}, 32 \pm 2 \mathrm{IU} / \mathrm{L} ; \gamma-\mathrm{GT}, 44 \pm 7 \mathrm{IU} / \mathrm{L}$; caspase-cleaved CK-18, 140.6 \pm 16.3U/L; and L-FABP, $18.2 \pm$ $1.5 \mathrm{ng} / \mathrm{mL}$; all $P<.05)$. After 6 months, levels of ALT and $\gamma$-GT had further decreased (ALT, $28 \pm 2 \mathrm{IU} / \mathrm{L}$ and $\gamma$-GT, $35 \pm$ $5 \mathrm{IU} / \mathrm{L})$, whereas levels of AST, caspase-cleaved CK-18, and L-FABP had stabilized ( $P=$ not significant). Six months after DJBLs were removed, levels of ALT (37 $\pm 3 \mathrm{IU} / \mathrm{L}), \gamma-\mathrm{GT}$ (42 $\pm 5 \mathrm{IU} / \mathrm{L})$, and caspase-cleaved CK-18 (124.5 \pm 12.5U/L) were still reduced $(P<.05)$, whereas AST and L-FABP had returned to near baseline levels ( $P=$ not significant). Therefore, in obese subjects, DJBL reduces plasma parameters of NAFLD. ClinicalTrials.gov, Number: NCT00985114.

Keywords: Insulin Resistance; Intestine; Stomach; Steatosis.

$\mathrm{R}$ ecently, a nonsurgical bariatric technique, the duodenal-jejunal bypass liner (DJBL) (GI Dynamics, Lexington, MA), was developed. The initial purpose of the DJBL was to treat obesity. ${ }^{1}$ Remarkably, this device turned out to not only lead to significant weight loss but also to rapid improvement of type 2 diabetes. $^{2,3}$ Because both conditions are important risk factors for nonalcoholic fatty liver disease (NAFLD) ${ }^{4,5}$ and previous research with surgical bariatric techniques has revealed beneficial effects on NAFLD, ${ }^{6-9}$ we hypothesized that DJBL treatment would also have a favorable impact on NAFLD. We therefore investigated the effect of DJBL treatment on plasma parameters that have been linked to NAFLD. Changes in aspartate aminotransferase (AST), alanine aminotransferase (ALT), $\gamma$-glutamyltransferase $(\gamma$-GT), liver fatty acid-binding protein (L-FABP), caspase-cleaved cytokeratin-18 (CK-18), and albumin in obese subjects with type 2 diabetes before, during, and after DJBL treatment are reported.

\section{Methods \\ Subjects}

Seventeen subjects with obesity and type 2 diabetes were included in the study by the Maastricht University Medical Center, Maastricht, and the Atrium Medical Center Parkstad, Heerlen, the Netherlands. Inclusion criteria were age 18-65 years, body mass index (BMI) $30-50 \mathrm{~kg} / \mathrm{m}^{2}$, duration of type 2 diabetes $<10$ years, and glycosylated hemoglobin $7.5 \%-10.0 \%$. Main exclusion criteria were alcohol consumption $>1$ unit/day for women or $>2$ units/ day for men, weight loss $>4.5 \mathrm{~kg}$ within 12 weeks before screening, use of weight loss medication or anti-inflammatory drugs, history of inflammatory diseases or other known liver diseases than NAFLD, and exclusion criteria regarding DJBL compatibility. The study was approved by the Medical Ethics Committee of each center and conducted according to the revised version of the Declaration of Helsinki (October 2008, Seoul). Written informed consent was obtained before study participation.

\section{Duodenal-Jejunal Bypass Liner Treatment}

Subjects were treated with the DJBL for 24 weeks. The DJBL was delivered and retrieved endoscopically as described previously. ${ }^{1}$ Subjects were provided a standard of care nutritional counseling program, which suggested a regular diet with a maximum of $1200 \mathrm{kcal}$ for women and $1500 \mathrm{kcal}$ for men that was liquid for the first week after DJBL placement. Dietary adaptations were made during follow-up if necessary.

\section{Study Design}

Subjects were studied on 4 occasions: within 1 month before the start of the study (D0), 3 and 6 months after

Abbreviations used in this paper: ALT, alanine aminotransferase; AST, aspartate aminotransferase; BMI, body mass index; CK-18, cytokeratin-18; DJBL, duodenal-jejunal bypass liner; $\gamma$-GT, gamma-glutamyltransferase; L-FABP, liver fatty acid-binding protein; NAFLD, nonalcoholic fatty liver disease; NASH, nonalcoholic steatohepatitis.

(C) 2013 by the AGA Institute 1542-3565/\$36.00

http://dx.doi.org/10.1016/j.cgh.2013.07.029 
Table 1. Baseline Characteristics of the Study Population

\begin{tabular}{lccccc}
\hline & D0, baseline & M3, treatment & M6, treatment & M12, after treatment & Reference limit \\
\hline Weight $(\mathrm{kg})$ & $116.0 \pm 5.8$ & $105.3 \pm 5.5$ & $103.3 \pm 5.5$ & $106.7 \pm 6.1$ & \\
BMI $\left(\mathrm{kg} / \mathrm{m}^{2}\right)$ & $37.0 \pm 1.3$ & $33.6 \pm 1.2$ & $32.9 \pm 1.2$ & $34.3 \pm 1.5$ & Male $<35 ;$ female $<30$ \\
AST $(I U / L)$ & $35 \pm 4$ & $28 \pm 3$ & $23 \pm 2$ & $34 \pm 3$ & Male $<45 ;$ female $<35$ \\
ALT $(I U / L)$ & $54 \pm 5$ & $32 \pm 2$ & $28 \pm 2$ & $37 \pm 3$ & Male $<55 ;$ female $<40$ \\
$\gamma$-GT $(I U / L)$ & $66 \pm 14$ & $44 \pm 7$ & $20.2 \pm 1.6$ & $29.5 \pm 3.1$ & \\
L-FABP $(n g / m L)$ & $29.3 \pm 2.6$ & $18.2 \pm 1.5$ & $149.2 \pm 23.1$ & $124.5 \pm 12.5$ & \\
CK-18 $(U / L)$ & $214.4 \pm 35.6$ & $140.6 \pm 16.3$ & $149.2 \pm 5$ & \\
\hline
\end{tabular}

NOTE. Data are shown as mean \pm standard error of the mean.

implantation of the DJBL (M3 and M6, respectively), and again 6 months after explantation of the DJBL (M12). The baseline visit included physical examination and history taking. At all study visits, body weight was determined, and fasting venous blood samples were collected (BD Vacutainer EDTA tube; BD Diagnostics, Erembodegem-Aalst, Belgium). Samples were immediately cooled, centrifuged, and stored at $-80^{\circ} \mathrm{C}$ until further analysis.

\section{Plasma Parameters}

Plasma levels of AST, ALT, $\gamma$-GT, albumin, and glycosylated hemoglobin were determined routinely at the Department of Clinical Chemistry at the Maastricht University Medical Center. Reference limits can be found in Table 1.

Recent reports indicate that plasma levels of caspase-cleaved CK-18 reflect hepatocyte apoptosis and are closely related to NAFLD severity. ${ }^{10-13}$ We therefore determined this parameter by using an enzyme-linked immunosorbent assay (caspasecleaved CK-18: M30 Apoptosense ELISA; Peviva AB, Bromma, Sweden). In addition, an enzyme-linked immunosorbent assay was used to determine plasma L-FABP concentrations (L-FABP ELISA, provided by Hycult Biotechnology, Uden, the Netherlands).

\section{Statistical Analyses}

Statistical analyses were performed by using GraphPad Prism 5.0 (La Jolla, CA). Longitudinal changes were tested by using Wilcoxon signed rank test. A $P$ value $<.05$ was considered statistically significant. Data are presented as mean and standard error of the mean.

All co-authors had access to the study data and reviewed and approved the final manuscript.

\section{Results \\ Duodenal-Jejunal Bypass Liner Treatment Results in Significant Weight Loss}

At baseline, subjects were aged $51 \pm 2$ years, and the majority of subjects were male (14 of 17). Additional baseline characteristics of the study subjects and subsequent changes are shown in Table 1.

Three months after DJBL implantation, body weight had decreased from $116.0 \pm 5.8$ to $105.3 \pm 5.5 \mathrm{~kg}$, corresponding with an excess weight loss of $25.2 \% \pm 3.1 \%$ and a BMI reduction of $3.4 \pm 0.4 \mathrm{~kg} / \mathrm{m}^{2}(P<.01)$. After 24 weeks at the time of device explantation, weight had further decreased to $103.3 \pm 5.5 \mathrm{~kg}$, resulting in a total weight loss of $12.7 \pm$ $1.3 \mathrm{~kg}$, corresponding to an excess weight loss of $29.8 \% \pm 3.5 \%$ and a BMI reduction of $4.1 \pm 0.4 \mathrm{~kg} / \mathrm{m}^{2}(P<.01)$. Six months after explantation of the device (M12), body weight had increased slightly to $106.7 \pm 6.1 \mathrm{~kg}$ but was still significantly decreased when compared with baseline $(P<.01)$. BMI and excess weight loss were $34.3 \pm 1.5 \mathrm{~kg} / \mathrm{m}^{2}$ and $19.9 \% \pm 3.9 \%$, respectively.

\section{Established Clinical Plasma Liver Parameters Decrease After Duodenal-Jejunal Bypass Liner Implantation}

To gain insight into the potential effects of DJBL treatment on NAFLD, several established clinical plasma parameters that have been linked to NAFLD ${ }^{14,15}$ were evaluated. At baseline, mean plasma AST level was $35 \pm 4 \mathrm{IU} / \mathrm{L}$ (Figure $1 A$ ). In addition, plasma ALT and $\gamma$-GT were above the upper reference limits $(54 \pm 5 \mathrm{IU} / \mathrm{L}$ and $66 \pm 14 \mathrm{IU} / \mathrm{L}$, respectively; Figure $1 B$ and $C)$.

Three months after DJBL implantation, plasma AST had decreased from $35 \pm 4$ to $28 \pm 3 \mathrm{IU} / \mathrm{L}(P<.05)$. AST levels continued to decrease, and 6 months after implantation the mean AST level was $23 \pm 2 \mathrm{IU} / \mathrm{L}(P<.01)$. Furthermore, a significant reduction in ALT levels was observed from $54 \pm 5$ at baseline to $32 \pm 2 \mathrm{IU} / \mathrm{L}$ after 3 months and to $28 \pm 2 \mathrm{IU} / \mathrm{L}$ after 6 months (both $P<.01$ ). The $\gamma$-GT levels also decreased from $66 \pm 14 \mathrm{IU} / \mathrm{L}$ at baseline to $44 \pm 7$ and $35 \pm 5 \mathrm{IU} / \mathrm{L}$ at 3 and 6 months after DJBL implantation, respectively (both $P<.01)$.

Six months after explantation of the device at month 12, AST had increased and returned to baseline levels $(34 \pm 3 \mathrm{IU} / \mathrm{L}$, $P=.63)$. In contrast, ALT and $\gamma$-GT levels were still diminished (ALT: $37 \pm 3 \mathrm{IU} / \mathrm{L}, \gamma$-GT: $42 \pm 5 \mathrm{IU} / \mathrm{L}$; both $P<.01$ ). Albumin levels of all subjects, data not shown, stayed within the reference range at all times.

\section{Duodenal-Jejunal Bypass Liner Treatment Rapidly Reduces Plasma Markers of Liver Damage and Liver Apoptosis}

The effect of DJBL treatment on NAFLD-related liver damage, reflected by a marker of hepatocyte injury, L-FABP ${ }^{16}$ is shown in Figure $1 D$. Plasma L-FABP levels decreased from 29.3 $\pm 2.6 \mathrm{ng} / \mathrm{mL}$ at baseline to $18.2 \pm 1.5 \mathrm{ng} / \mathrm{mL}$ after 3 months of treatment $(P<.01)$. Until month 6 , plasma L-FABP levels stayed at a lower level $(20.2 \pm 1.6 \mathrm{ng} / \mathrm{mL}, P<.05)$. At month 12 , six months after device removal, L-FABP levels had returned to baseline level $(29.5 \pm 3.1 \mathrm{ng} / \mathrm{mL}, P=.85)$.

We next determined the effect of DJBL treatment on hepatocyte apoptosis, as indicated by plasma caspase-cleaved CK-18 concentrations. Changes in caspase-cleaved CK-18 
Figure 1. Effects of DJBL treatment on AST, ALT, $\gamma$-GT, L-FABP, and caspase-cleaved CK-18. (A) Plasma AST levels at baseline (D0) and 3 (M3) and 6 (M6) months after implantation of DJBL and 6 months after removal of DJBL (M12). (B) Plasma levels of ALT at these time points, whereas (C) shows plasma concentrations of $\gamma$-GT. (D) Plasma L-FABP levels at these time points. (E) Plasma levels of caspase-cleaved CK-18 at these time points. ${ }^{\star} P<.05$; ${ }^{\star \star} P<.01$.
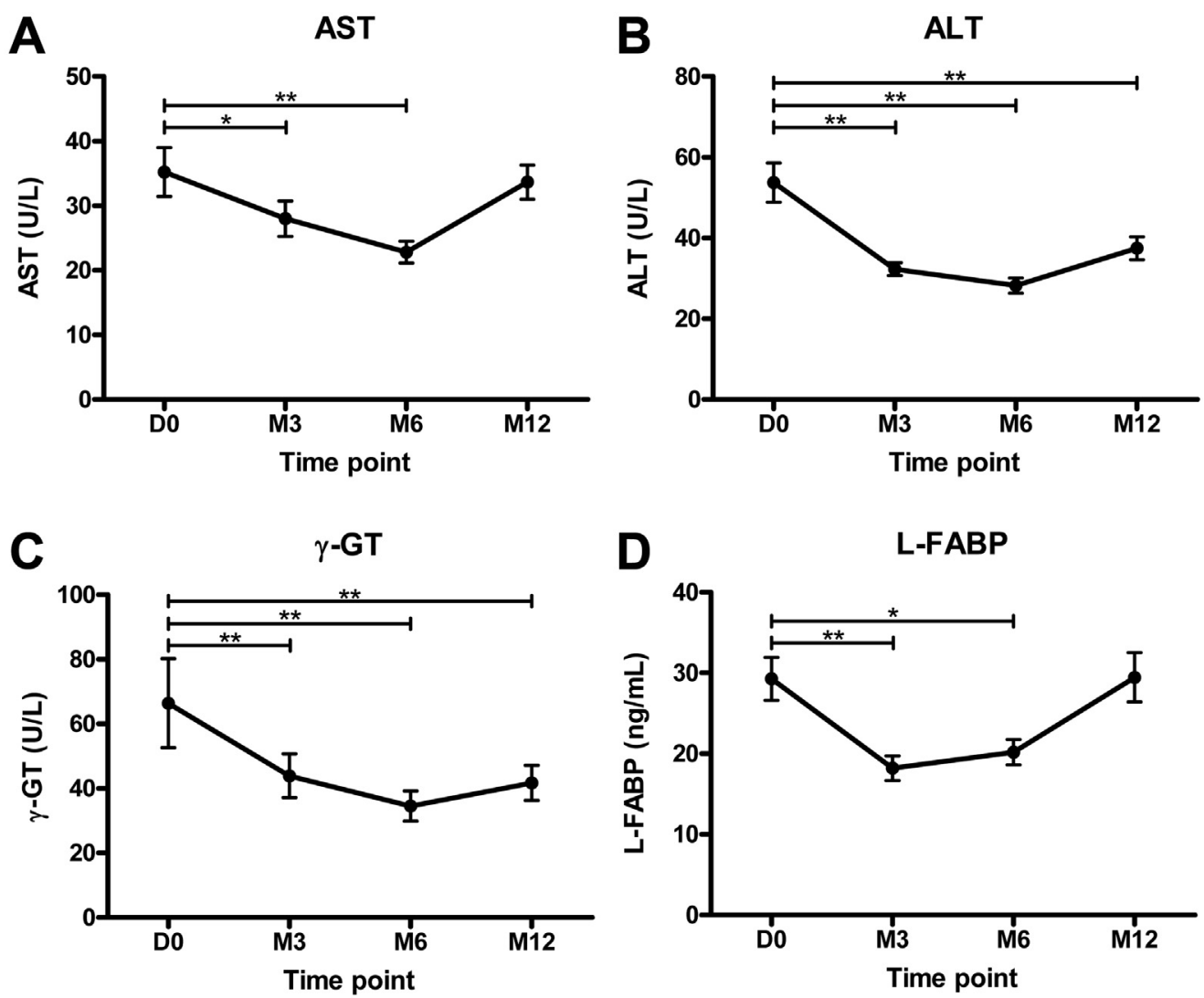

showed a similar pattern as the changes in L-FABP concentration (Fig. 1E). At baseline, caspase-cleaved CK-18 levels were $214.4 \pm 35.6 \mathrm{U} / \mathrm{L}$. After 3 months, the levels had decreased to $140.6 \pm 16.3 \mathrm{U} / \mathrm{L}(P<.05)$. During the remainder of the study, the decrease in caspase-cleaved CK-18 concentrations stabilized $(149.2 \pm 23.1 \mathrm{U} / \mathrm{L}$ at month 6 and $124.5 \pm 12.5 \mathrm{U} / \mathrm{L} 6$ months after DJBL removal; $P=.12$ and $P<.01$, respectively).

\section{Discussion}

Bariatric surgery effectively treats obesity and also leads to improvement of NAFLD. ${ }^{6-9}$ However, bariatric surgery is invasive and associated with complications, causing a hesitative attitude in patients toward this type of surgery. ${ }^{17}$ Therefore, there is need for less invasive devices like the DJBL. The DJBL has been shown to be safe and effective in treating obesity and different aspects of metabolic syndrome, including type 2 diabetes. ${ }^{1-3}$ The effect of DJBL treatment on plasma parameters that are associated with NAFLD was investigated in the current study. We report that plasma liver parameters improve after duodenal-jejunal exclusion by DJBL.

In the current study with a minimally invasive bariatric technique, we chose not to expose our subjects to repeated invasive liver biopsies, but instead, plasma parameters reflecting NAFLD were used. Our data show that clinical plasma liver parameters decreased after DJBL implantation. Normalization of AST, ALT, and $\gamma$-GT levels occurred in almost all subjects. 
Dixon et $\mathrm{al}^{18}$ have shown that a decrease in $\gamma$-GT and AST levels is associated with improvement of liver histology in NAFLD patients after weight loss by bariatric surgery. This advocates for improvement of NAFLD by DJBL treatment in our subjects. In addition, DJBL treatment resulted in diminished plasma levels of L-FABP, a small intracellular protein that rapidly leaks out of damaged hepatocytes into the circulation. ${ }^{16}$ A similar response pattern was observed for caspasecleaved CK-18. Caspase-cleaved CK-18 is a protein generated during hepatocyte apoptosis, a prominent pathologic feature of nonalcoholic steatohepatitis (NASH), ${ }^{19}$ the more severe form of NAFLD. Plasma levels of caspase-cleaved CK-18 positively correlate with NAFLD severity, independently predicting the presence of NASH. ${ }^{10-13}$ In our subjects, a decrease in caspasecleaved CK-18 was observed after initiation of the DJBL treatment, potentially indicating NASH regression. Taken together, all plasma parameters associated with NAFLD improved after DJBL implantation. Interestingly, 6 months after DJBL removal, ALT, $\gamma$-GT, and caspase-cleaved CK-18 were still diminished when compared with baseline, suggesting a sustained effect of the DJBL treatment.

Notably, NAFLD severity was probably limited in our study population, which was characterized by modest elevation of plasma liver parameters. ${ }^{10,13}$ The subjects are therefore probably in an early, still reversible stage of NAFLD, when cure through intervention is still possible. ${ }^{20}$

In conclusion, a rapid improvement of all NAFLD parameters after initiation of DJBL treatment was observed. It appears that the DJBL reverses liver parameters associated with NAFLD at least temporarily. Further research evaluating longer-term follow-up and/or histologic changes of the liver is needed to fully elaborate the potential positive effect of DJBL treatment on NAFLD.

\section{References}

1. Schouten R, Rijs CS, Bouvy ND, et al. A multicenter, randomized efficacy study of the EndoBarrier Gastrointestinal Liner for presurgical weight loss prior to bariatric surgery. Ann Surg 2010; 251:236-243.

2. Escalona A, Pimentel F, Sharp A, et al. Weight loss and metabolic improvement in morbidly obese subjects implanted for 1 year with an endoscopic duodenal-jejunal bypass liner. Ann Surg 2012; 255:1080-1085.

3. de Jonge C, Rensen SS, Verdam FJ, et al. Endoscopic duodenal-jejunal bypass liner rapidly improves type 2 diabetes. Obes Surg 2013; 23:1354-1360.

4. Angulo P. Obesity and nonalcoholic fatty liver disease. Nutrition Reviews 2007;65:63.

5. Lazo M, Clark JM. The epidemiology of nonalcoholic fatty liver disease: a global perspective. Semin Liver Dis 2008;28:339-350.

6. Blackburn GL, Mun EC. Effects of weight loss surgeries on liver disease. Semin Liver Dis 2004;24:371-379.

7. Mattar SG, Velcu LM, Rabinovitz M, et al. Surgically-induced weight loss significantly improves nonalcoholic fatty liver disease and the metabolic syndrome. Ann Surg 2005;242:610-620.

8. Mathurin P, Hollebecque A, Arnalsteen L, et al. Prospective study of the long-term effects of bariatric surgery on liver injury in patients without advanced disease. Gastroenterology 2009;137:532-540.
9. Rabl C, Campos GM. The impact of bariatric surgery on nonalcoholic steatohepatitis. Semin Liver Dis 2012;32:80-91.

10. Wieckowska A, Zein NN, Yerian LM, et al. In vivo assessment of liver cell apoptosis as a novel biomarker of disease severity in nonalcoholic fatty liver disease. Hepatology 2006;44:27-33.

11. Diab DL, Yerian L, Schauer P, et al. Cytokeratin 18 fragment levels as a noninvasive biomarker for nonalcoholic steatohepatitis in bariatric surgery patients. Clin Gastroenterol Hepatol 2008;6:1249-1254.

12. Feldstein A, Wieckowska A, Lopez A, et al. Cytokeratin-18 fragment levels as noninvasive biomarkers for nonalcoholic steatohepatitis: a multicenter validation study. Hepatology 2009;50:1072-1078.

13. Shen J, Chan HL, Wong GL, et al. Non-invasive diagnosis of nonalcoholic steatohepatitis by combined serum biomarkers. J Hepatol 2012;56:1363-1370.

14. Wieckowska A, McCullough AJ, Feldstein AE. Noninvasive diagnosis and monitoring of nonalcoholic steatohepatitis: present and future. Hepatology 2007;46:582-589.

15. Neuschwander-Tetri BA, Clark JM, Bass NM, et al. Clinical, laboratory and histological associations in adults with nonalcoholic fatty liver disease. Hepatology 2010;52:913-924.

16. Pelsers MM, Morovat A, Alexander GJ, et al. Liver fatty acidbinding protein as a sensitive serum marker of acute hepatocellular damage in liver transplant recipients. Clin Chem 2002; 48:2055-2057.

17. Afonso BB, Rosenthal R, Li KM, et al. Perceived barriers to bariatric surgery among morbidly obese patients. Surg Obes Relat Dis 2010; 6:16-21.

18. Dixon JB, Bhathal PS, O'Brien PE. Weight loss and non-alcoholic fatty liver disease: falls in gamma-glutamyl transferase concentrations are associated with histologic improvement. Obes Surg 2006; 16:1278-1286.

19. Feldstein AE, Canbay A, Angulo P, et al. Hepatocyte apoptosis and fas expression are prominent features of human nonalcoholic steatohepatitis. Gastroenterology 2003;125:437-443.

20. Smith BW, Adams LA. Non-alcoholic fatty liver disease. Crit Rev Clin Lab Sci 2011;48:97-113.

\section{Reprint requests}

Address requests for reprints to: Jan Willem M. Greve, MD, PhD, Atrium Medical Center Parkstad, PO Box 4446, 6401 CX Heerlen, the Netherlands. e-mail: j.greve@atriummc.nl; fax: +31-45-5713360.

\section{Acknowledgments}

The authors thank the subjects contributing to this trial; the trial nurses $Y$. Wils and R. Nelissen and the students who helped conduct this research: G. Latten, N. Geubbels, M. de Wolf, T. van der Horst, R. Erbil, B. van der Putten, H. D'Agnolo, and S. Peeters Weem; B. Winkens for statistical assistance; A. A. van Bijnen, B. T. Boonen, and M. Hadfoune for their laboratory assistance; Drs R. J. de Ridder and C. M. Bakker for their help with the DJBL procedures; and Prof Dr A. A. Masclee, Dr J. Maljaars, Y. Slaats, and Dr F. J. Verdam for their help regarding the study design.

Conflicts of interest

These authors disclose the following: Dr Bouvy received an open research grant from GI dynamics. Dr Greve received an open research grant from and is a consultant for GI Dynamics, and received support for travel to meetings for the study or other purposes from GI dynamics. The remaining authors disclose no conflicts.

\section{Funding}

Supported by an open research grant from GI Dynamics. 